\title{
Causes of Stress in Organization, a Case Study of Sukkur
}

\author{
Dr. Nadeem Bhatti \\ Head of Faculty, North American College \\ 730-Yonge Street, Suite No. 207 \\ Toronto, Ontario, M4Y 2B7, Canada \\ Amir Hussain Shar (Assistant Professor) \\ Department of Commerce, Shah Abdul Latif University \\ Khairpur, Pakistan \\ E-mail: amirhussainroshan@yaho.com \\ Faiz.M.Shaikh (Assistat Professor) \\ SZABAC-Dokri-Khairpur, Sindh, Pakistan \\ E-mail: faizmuhammed_2000@yahoo.com \\ Muhammad Suhail Nazar (Assistant Professor) \\ Department of Managemnent Sciences \\ Islamia University Bahawalpur
}

\begin{abstract}
The aim of this study is to investigate the main causes of stress for employees working in different industries in Sukkur and their vicinity. Stress is taken as dependent variable whereas independent variables are categorized into extra-organizational and intra-organizational stressors. Data were collected from different sectors such service, manufacturing and distribution including banks, insurance companies, manufacturing (LU Continental Biscuit Factory Sukkur and Engro Foods) and distribution (Medicine distribution firms). Data were collected through self-administrative questionnaire consisting of 20 questions. Respondents were only the employees working at operational level. From the results it was quite clear that employees working in different areas feel great stress, there were different causes due to which employee experience stress. Findings have been classified into extra-organizational and intra-organizational stressors. Extra-organizational stressors include variables such as climate, economic conditions and employee family, whereas intra-organizational stressors include variables such as company policies, working conditions, and leadership, workload and office timings. According to results $33 \%$ of overall stress is caused by factors outside organization whereas $67 \%$ stress is due to internal factors. It was also found that major cause of stress is workload (25\%) because employees are been utilized more than their capabilities, second major cause for stress is timings (16\%) as employees work for long hours, next cause for stress is climate $(11 \%)$ as employees especially from distribution side have to go outside offices to meet their clients and customers so hot weather, traveling distances and transportation system really give them tough time which result in stress. Next stressor is leadership as leader-employee relationship is needed to be very good but according to some employees their bosses do not behave well due to which they feel stressed. Other causes include economic, family, company policies and working conditions with percentage of $11 \%, 8 \%, 7 \%$ and $7 \%$ respectively.
\end{abstract}

Keywords: Stress, Organization, Sukkur

\section{Introduction}

Stress in the workplace is increasingly a critical problem for workers, employers and societies. Researchers who study stress in the United States have demonstrated the direct and indirect costs of stress (Matteson \& Ivancevich, 1987). While stress has been studied frequently in the West, there has been little research on the topic in Southeast Asia. One recent study carried out in the People's Republic of China found higher job stress for Chinese managers with Type A personalities (Xie \& Jamal, 1993), but little else has been reported in research 
journals. Pakistan appears to be a prime country in Southeast Asia to study stress due to the rapid transformation of the city-state from a British colony have had to adjust to both the positive and negative effects of the quickened pace of life in a modern, industrialized nation. In fact, a early as 1984, Cooper and Arbose noted, managers in Pakistan show a higher incidence of stress symptoms than managers in the other highly such as the United States, Britain, Germany and Sweden. ( $\mathrm{p} 22$ ) There are many variables which have been related to work stress. Ivancevich and Matteson (1980) proposed a model of organizational stress research which outlined the major antecedents of work stress. They noted the importance of individual differences as moderators of stress and detailed possible outcomes of stress at work. Haviovic \& Keenan (1991) in their recent work have again emphasized the importance of individual differences as moderators of job stress.

Role conflict and role ambiguity are among the antecedents of work stress which have been most cited in the research literature (Fisher \& Gitelson, 1983). Role conflict, that is pressure to perform in two or more incompatible ways, has been tied conclusively to occupational stress in Western research. It has also been demonstrated to be a factor in job dissatisfaction and propensity to leave the organization one works for ever since the classic work of Kahn and his colleagues (Kahn, Wolfe, Quinn, Snoeck \& Rosenthal, 1964; Rizzo, House \& Lirtzman, 1970; House \& Rizzo, 1972; Hamner \& Tosi, 1974; Van Sell, Brief \& Schuler, 1981; Stout \& Posner, 1984; Fang \& Baba, 1993; Cordes \& Dougherty, 1993). Role ambiguity, the lack of clear and specific information regarding work role requirements, has also been linked repeatedly with job stress and low job satisfaction (House \& Rizzo, 1972; Hamner \& Tosi, 1974; Ivancevich \& Donnelly, 1974; Wright \& Thomas, 1982; Cordes \& Dougherty, 1993). Since role conflict and role ambiguity are issues in most Western organizations, they must be faced by Pakistani managers as well.

Many individual difference variables have been studied as moderators, that is, as characteristics which may either intensify or weaken the relationship among role conflict/role ambiguity and job stress. Most of these are personality variables including the need for achievement (Johnson \& Stinson, 1975; Abdel-Halim, 1980), tolerance of ambiguity (Kahn, et al, 1964; Lyons, 1971; Ivancevich \& Donnelly, 1974; Miles \& Petty, 1975) and locus of control (Organ \& Greene, 1974; Szilagyi, Sims \& Keller, 1976; Abdel-Halim, 1980; Baths, 1980). The present study included two moderator variables - locus of control and tolerance of ambiguity. Locus of control was outlined by Rotter (1966) as the extent to which people believe that they control the outcomes in their lives (internal locus of control) versus those outcomes being dependent on fate, luck or powerful others (external locus of control). Research has frequently demonstrated that "internals" tolerate role ambiguity and role conflict better than "externals" and are less stressed (Organ \& Greene, 1974; Szilagyi, ci a!, 1976; Jackson \& Schuler, 1985). Locus of control may he particularly important to study in an Asian society where many people have been raised to believe that fate plays a big part in their success. This is indicated perhaps most graphically in the use of geomancers to specify the best dates to marry, to set up a business, to move to a new home, etc.

Stress is one of the key factor that mot $\mathrm{f}$ the workers are co-workers are facing today in the world but in Pakistan stress among various organization specially in Sukkur. According to results $33 \%$ of overall stress is caused by factors outside organization whereas $67 \%$ stress is due to internal factors. It was also found that major cause of stress is workload (25\%) because employees are been utilized more than their capabilities, second major cause for stress is timings $(16 \%)$ as employees work for long hours, next cause for stress is climate (11\%) as employees especially from distribution side have to go outside offices to meet their clients and customers so hot weather, traveling distances and transportation system really give them tough time which result in stress. Next stressor is leadership as leader-employee relationship is needed to be very good but according to some employees their bosses do not behave well due to which they feel stressed.

\section{Data collection Methodology}

Data were collected from different sectors such as services, manufacturing and distribution including banks, insurance companies, manufacturing (LU Continental Biscuit Factory Sukkur and Engro Foods) and distribution (Medicine distribution firms). Data was collected through self-administrative questionnaire consisting of 20 questions. Respondents were only the employees working at operational level. From the results it was quite clear that employees working in different areas feel great stress, there were different causes due to which employee experience stress. Findings have been classified into extra-organizational and intra-organizational stressors.

\section{Findings}

According to our results there are so many causes of stress which are categorized into:

\section{Extra Organizational Stressors}

- Climate 
- Economic

- Family

2. Intra-Organizational Stressors

- Leadership

- Company Policies

- Working Conditions

- Workload

- Office Timings

As our study covers the all areas of business, results are presented according to respective business area including service, manufacturing and trading organizations. Findings are categorized into overall causes of stress in all business, causes of stress in each sector and finally effect of each variable in different sectors. Following table represents the overall result in percentage form.

\section{Classification of Stressors}

\subsection{Extra-organizational Stressors}

It is believed that stress is only caused by the factors inside the organization but this study proves that there are certain outside factors which cause stress for employees and as a result of those employees' performance is affected. According to results $33 \%$ of overall stress is caused by factors outside organization. Following chart shows percentage wise distribution of extra-organizational stressors.

\section{Insert Figure 1}

This chart shows that $42 \%$ extra-organizational stress is caused by climate factor, as in Sukkur there are warm conditions so employees feel a lot of stress during traveling specially marketing personnel who have to do out door job. Second major extra-organizational stressor is economic which $32 \%$, as economic conditions of Pakistan are not too good and due to inflation purchasing power is reducing so people find it really difficult to fulfill their needs this ultimately results into stress. Last extra-organizational stressor is family, as employees have to spend a lot of time in their jobs especially people who are working in service organizations such as banks they hardly give any time to their families and as a result of it they are mentally upset and feel stress.

\subsection{Intra-organizational Stressors}

These stressors are present within the organization. In our study $67 \%$ of overall stress is caused by internal factors. Following chart shows the percentage wise distribution of factors present within the organization.

\section{Insert Figure 2 here}

It is obvious from the chart that major cause of stress is workload, as employees are provided with really tough tasks and some believes they are asked to work more than their capabilities, and then the next stressor is timings with $23 \%$ as it was said by most of employee especially working at banks that there is timing of coming to bank but there is no specific time to return their homes, therefore due to long hours of work they experience stress. The next cause for stress is leadership (18\%) as most of bosses do not have good behavior with subordinates so employees are not comfortable at all. Working conditions also cause stress these includes work environment, physical facilities and co-workers. Company policies stand last in terms of causing stress these policies include all rules and regulations concerning jobs such as salaries, vacations, bonuses, recognition, promotion policies etc.

\section{Overall Causes of Stress in All Businesses}

Earlier percentages were assigned to causes according to their category i.e. within the organization and outside the organization. Now have a look at overall distribution of percentage to each variable in all businesses.

\section{Insert Figure 3}

It is clear from the chart that major cause of stress is workload (25\%) because employees are been utilized more than their capabilities, second major cause for stress is timings $(16 \%)$ as employees work for long hours, next cause for stress is climate (11\%) as employees especially from distribution side have to go outside offices to meet their clients and customers so hot weather, traveling distances and transportation system really give them tough time which result in stress. Next stressor is leadership as leader-employee relationship is needed to be very good but according to some employees their bosses do not behave well due to which they feel stressed. Other 
causes include economic, family, company policies and working conditions with percentage of $11 \%, 8 \%, 7 \%$ and $7 \%$ respectively.

\section{Sector wise causes of stress}

3.1 Causes of Stress in Service Organizations

\section{Insert Table 1}

\section{Insert Figure 4}

\subsection{Causes of Stress in Manufacturing Organizations}

Insert Table 2

Insert Figure 5

Insert Figure 6

3.3 Causes of Stress in Distribution Organizations

\section{Insert table 3}

\section{Effect of each variable on individual area of Business}

This is very important analysis because this suggests how different variable differ in each area of business. Results show the percentage effect of each variable in three different areas of business i.e. service, manufacturing and distribution.

4.1 Climate

Insert Table 4

Insert Figure 7

4.2 Economic

Insert Table 5

Insert Figure 8

4.3 Family

Insert Table 6

Insert Figure 9

4.4 Company Policies

Insert Table7

Insert Figure 10

4.5 Leadership

Insert Table 8

Insert Figure 11

$4.6 \mathrm{Workload}$

Insert Table 9

Insert Figure 12

4.7 Working Conditions

Insert Table 10

Insert Figure 13

4.8 Timings

Insert Table 11

Insert Table 14.

Insert Table 15. 


\section{Conclusion}

The current research highlight the causes of stress among employees in Sukkur and their vicinity. According to the survey results Stress is positively correlated to the stress. Intraorganizational stress like climate 14\%, Economic, 11 , and family $8 \%$. The results from extra-organizational stress company politics $7 \%$, leadership $12 \%$, Workload $25 \%$ working conditions $7 \%$ and timings $16 \%$. It is clear from the chart that major cause of stress is workload $(25 \%)$ because employees are been utilized more than their capabilities, second major cause for stress is timings $(16 \%)$ as employees work for long hours, next cause for stress is climate (11\%) as employees especially from distribution side have to go outside offices to meet their clients and customers so hot weather, traveling distances and transportation system really give them tough time which result in stress.

\section{References}

Abdel-Halim, A. (1980). Effects of person-job compatibility on managerial reactions to role ambiguity, Organizational Behavior and Human Performance, 26, pp. 193-211.

Baths, N. (1980). Job involvement and locus of control as moderators of role-perception/individual outcome relationships, Psychological Reports, 46, pp. 111-119.

Brayfield, A., and Rothe, H. (1951). An index of job satisfaction. Journal of Applied Psychology, 35, pp. $307-311$.

Budner, S. (1962). Intolerance of ambiguity as a personality variable. Journal of Personality, 30, pp. $29-50$.

Cooper, C., and Arbose, J. (1984). Executive stress goes global. International Management, May, pp. 22 -28.

Cordes, C., and Dougherty, T. (1993). A review and an integration of research on job burnout. Academy of Management Review, 18, pp. 621-656.

Fang, Y., and Baba, V. (1993). Stress and turnover intention: A comparative study among nurses. International Journal of Comparative Sociology, 34, pp. 24-38.

Fisher, C., and Gitelson, R. (1983). A meta-analysis of role conflict and ambiguity. Journal of Applied Psychology, 68, pp. 320-333.

Hamner, W., and Tosi, H. (1974). Relationship of role conflict and role ambiguity to job involvement measures. Journal of Applied Psychology, 59, pp. 497-499.

Haviovic, S., and Keenan, A. (1991). Coping with work stress: The influence of individual differences. Journal of Social Behavior and Personality, 6, pp. 199-212.

House, R., and Rizzo, J. (1972). Role conflict and role ambiguity as critical variables in a model of behavior. Organizational Behavior and Human Performance, 7, pp. 467-505.

Ivancevich, J., and Donnelly, J. (1974). A study of role clarity and need for clarity for three occupational groups. Academy of Management Journal, 17, pp. 28-36.

Ivancevich, J., and Matteson, M. (1980). Stress at Work, Scot. Foresnian, Glenview, Illinois.

Ivancevich, J., Matteson, M., Freedman, S., and Philips, J. (1990). Worksite stress management interventions. American Psychologist, 45, pp. 252-261.

Jackson, S., and Schuler, R. (1985). A meta-analysis and conceptual critique of research on role ambiguity and role conflict in work settings. Organizational Behavior and Human Decision Processes, 36, pp. 16-78.

Jenner, 1. (1986). A measure of chronic organizational stress. Psychological Reports, 58, pp. 543-546 
Table 1.

Table 2.

\begin{tabular}{|l|c|}
\hline \multicolumn{1}{|c|}{ Variables } & Percentage \\
\hline Intra-organizational & \\
\hline Climate & $11 \%$ \\
\hline Economic & $8 \%$ \\
\hline Family & $14 \%$ \\
\hline Extra-organizational & \\
\hline Company Policies & $10 \%$ \\
\hline Leadership & $11 \%$ \\
\hline Workload & $19 \%$ \\
\hline Working Conditions & $4 \%$ \\
\hline Timings & $23 \%$ \\
\hline Total & $100 \%$ \\
\hline
\end{tabular}

\begin{tabular}{|l|c|}
\hline \multicolumn{1}{|c|}{ Variables } & Percentage \\
\hline Intra-organizational & \\
\hline Climate & $6 \%$ \\
\hline Economic & $15 \%$ \\
\hline Family & $4 \%$ \\
\hline Extra-organizational & \\
\hline Company Policies & $11 \%$ \\
\hline Leadership & $19 \%$ \\
\hline Workload & $\mathbf{2 7 \%}$ \\
\hline Working Conditions & $10 \%$ \\
\hline Timings & $\mathbf{8 \%}$ \\
\hline Total & $100 \%$ \\
\hline
\end{tabular}

Table 3.

\begin{tabular}{|l|c|}
\hline \multicolumn{1}{|c|}{ Sector } & Percentage \\
\hline Service & $26 \%$ \\
\hline Manufacturing & $14 \%$ \\
\hline Distribution & $60 \%$ \\
\hline Total & $100 \%$ \\
\hline
\end{tabular}

Table 4.

\begin{tabular}{|l|c|}
\hline \multicolumn{1}{|c|}{ Sector } & Percentage \\
\hline Service & $25 \%$ \\
\hline Manufacturing & $47 \%$ \\
\hline Distribution & $28 \%$ \\
\hline Total & $100 \%$ \\
\hline
\end{tabular}

Table 5.

\begin{tabular}{|l|c|}
\hline \multicolumn{1}{|c|}{ Sector } & Percentage \\
\hline Service & $56 \%$ \\
\hline Manufacturing & $16 \%$ \\
\hline Distribution & $28 \%$ \\
\hline Total & $100 \%$ \\
\hline
\end{tabular}


Table 6.

Table 7 .

\begin{tabular}{|l|c|}
\hline \multicolumn{1}{|c|}{ Sector } & Percentage \\
\hline Service & $\mathbf{4 5 \%}$ \\
\hline Manufacturing & $\mathbf{5 0 \%}$ \\
\hline Distribution & $\mathbf{5 \%}$ \\
\hline Total & $\mathbf{1 0 0 \%}$ \\
\hline
\end{tabular}

Table 8 .

\begin{tabular}{|c|c|}
\hline Sector & Percentage \\
\hline Service & $\mathbf{3 1 \%}$ \\
\hline Manufacturing & $\mathbf{5 2 \%}$ \\
\hline Distribution & $\mathbf{1 7 \%}$ \\
\hline Total & $\mathbf{1 0 0 \%}$ \\
\hline
\end{tabular}

\begin{tabular}{|l|c|}
\hline \multicolumn{1}{|c|}{ Sector } & Percentage \\
\hline Service & $\mathbf{2 6 \%}$ \\
\hline Manufacturing & $\mathbf{3 6 \%}$ \\
\hline Distribution & $\mathbf{3 8 \%}$ \\
\hline Total & $\mathbf{1 0 0 \%}$ \\
\hline
\end{tabular}

Table 9.

Table 10.

\begin{tabular}{|l|c|}
\hline \multicolumn{1}{|c|}{ Sector } & Percentage \\
\hline Service & $18 \%$ \\
\hline Manufacturing & $45 \%$ \\
\hline Distribution & $37 \%$ \\
\hline Total & $100 \%$ \\
\hline
\end{tabular}

Table 11.

\begin{tabular}{|l|c|}
\hline \multicolumn{1}{|c|}{ Sector } & Percentage \\
\hline Service & $49 \%$ \\
\hline Manufacturing & $17 \%$ \\
\hline Distribution & $34 \%$ \\
\hline Total & $100 \%$ \\
\hline
\end{tabular}

Causes of Stress

\begin{tabular}{|c|c|c|c|}
\hline Variables & Service & Manufacturing & Trading \\
\hline Extra-organizational & \multicolumn{3}{|c|}{} \\
\hline Climate & $11 \%$ & $6 \%$ & $25 \%$ \\
\hline Economic & $8 \%$ & $15 \%$ & $9 \%$ \\
\hline Family & $14 \%$ & $4 \%$ & $7 \%$ \\
\hline Intra-organizational & & & $1 \%$ \\
\hline Company Policies & $10 \%$ & $11 \%$ & $6 \%$ \\
\hline Leadership & $11 \%$ & $19 \%$ & $28 \%$ \\
\hline Workload & $19 \%$ & $27 \%$ & $8 \%$ \\
\hline Working & $4 \%$ & $10 \%$ & $16 \%$ \\
\hline Conditions & $23 \%$ & $8 \%$ & $100 \%$ \\
\hline Timings & $100 \%$ & $100 \%$ & \\
\hline Total & & & \\
\hline
\end{tabular}


Table 12.

\section{Table 13.}

\begin{tabular}{|l|c|}
\hline \multicolumn{1}{|c|}{ Variables } & Percentage \\
\hline Intra-organizational & \\
\hline Climate & $14 \%$ \\
\hline Economic & $11 \%$ \\
\hline Family & $\mathbf{8 \%}$ \\
\hline Extra-organizational \\
\hline Company Policies & $7 \%$ \\
\hline Leadership & $12 \%$ \\
\hline Workload & $25 \%$ \\
\hline Working Conditions & $7 \%$ \\
\hline Timings & $16 \%$ \\
\hline Total & $100 \%$ \\
\hline
\end{tabular}

\begin{tabular}{|l|c|}
\hline \multicolumn{1}{|c|}{ Variables } & Percentage \\
\hline Intra-organizational & \\
\hline Climate & $\mathbf{2 5 \%}$ \\
\hline Economic & $\mathbf{9 \%}$ \\
\hline Family & $\mathbf{7 \%}$ \\
\hline Extra-organizational & \\
\hline Company Policies & $\mathbf{1 1 \%}$ \\
\hline Leadership & $\mathbf{6 \%}$ \\
\hline Workload & $\mathbf{2 8 \%}$ \\
\hline Working Conditions & $\mathbf{8 \%}$ \\
\hline Timings & $\mathbf{8 \%}$ \\
\hline Total & $\mathbf{1 0 0 \%}$ \\
\hline
\end{tabular}

Extraorganizational Stressors

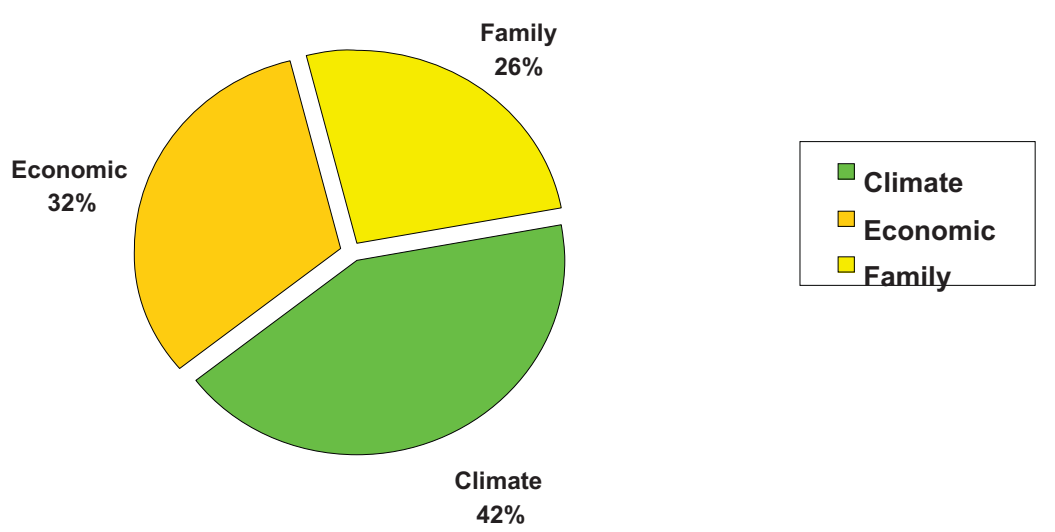

Figure 1. 


\section{Intraorganizational Stressors}

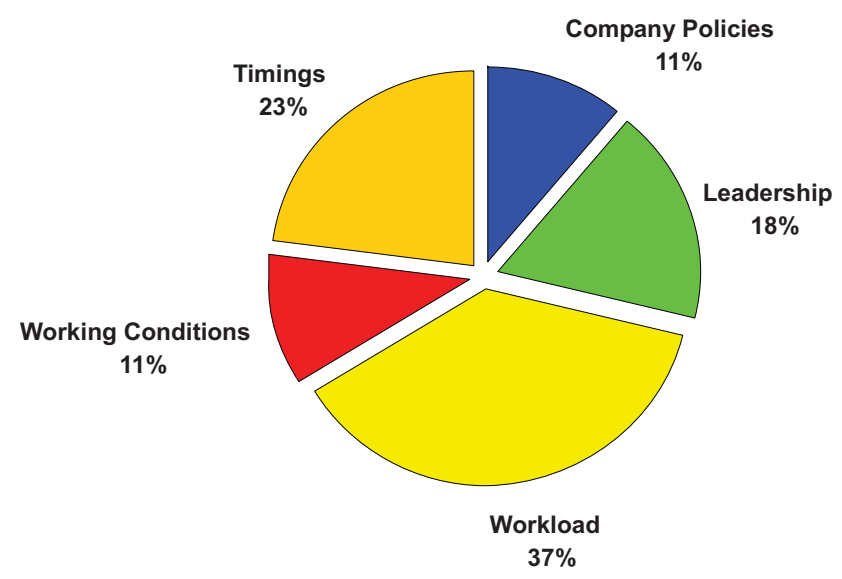

\begin{tabular}{|l}
\hline Company Policies \\
$\square$ Leadership \\
$\square$ Workload \\
$\square$ Working Conditions \\
$\square$ Timings
\end{tabular}

Figure 2 .

Causes of Stress in All Businesses

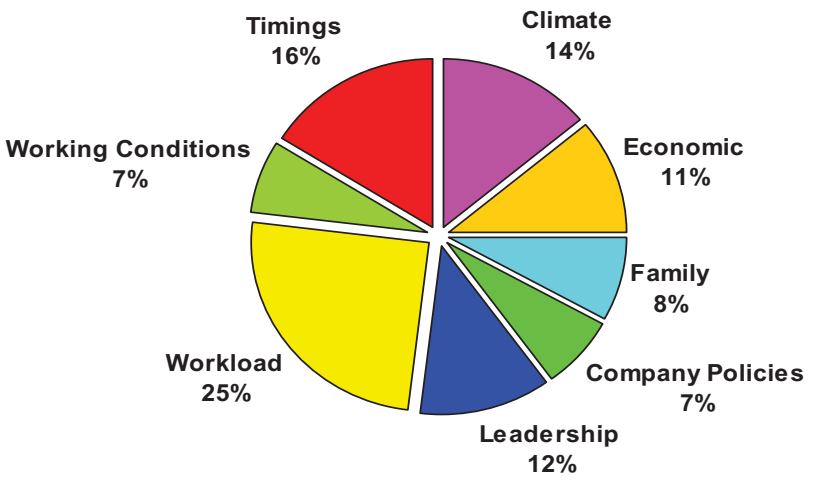

Figure 3.

Causes of Stress in Service Organizations

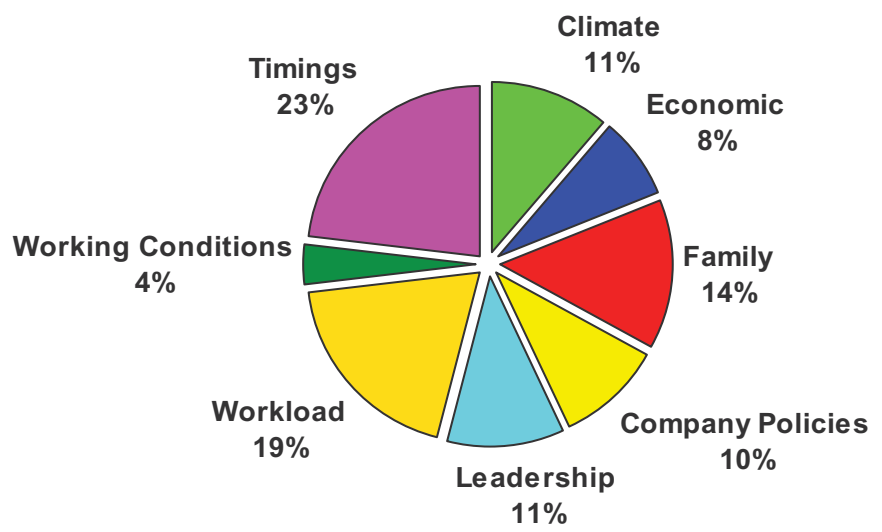

Figure 4.

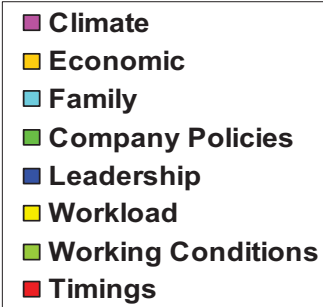

\begin{tabular}{|l|}
\hline Climate \\
$\square$ Economic \\
$\square$ Family \\
$\square$ Company Policies \\
$\square$ Leadership \\
$\square$ Workload \\
$\square$ Working Conditions \\
$\square$ Timings
\end{tabular}

Economic

Family

Company Policie

$\square$ Leadership

Working Conditions

Timings 
Causes of Stress in Manufacturing Organizations

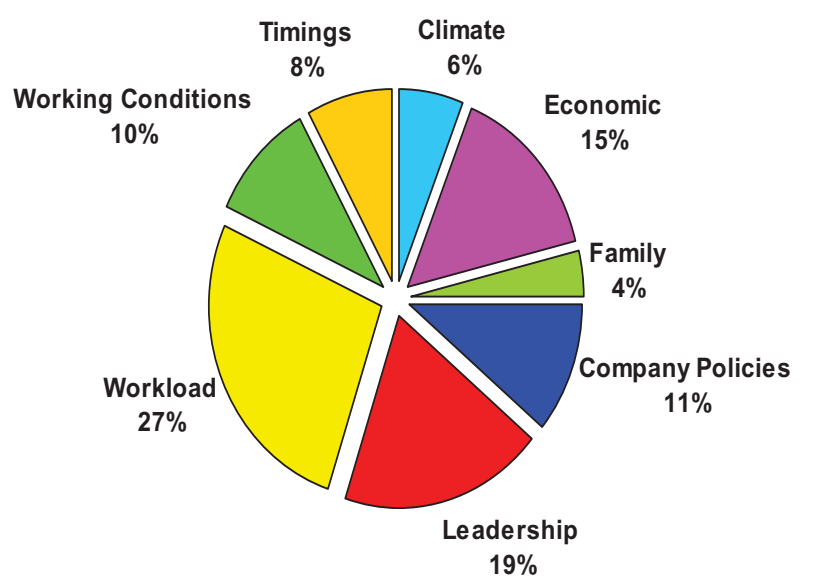

Figure 5.

\begin{tabular}{|l|}
\hline Climate \\
$\square$ Economic \\
$\square$ Family \\
$\square$ Company Policies \\
$\square$ Leadership \\
$\square$ Workload \\
$\square$ Working Conditions \\
$\square$ Timings \\
\hline
\end{tabular}

$\square$ Climate

$\square$ Economic

$\square$ Family

口 Company Policies

口 Leadership

Workload

$\square$ Timings

\section{Causes of Stress in Distribution Organizations}

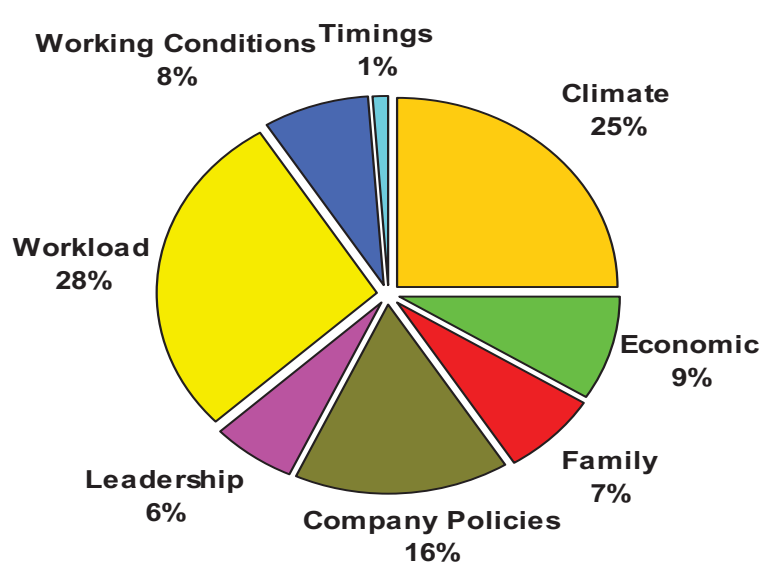

Figure 6.

\begin{tabular}{|l|}
\hline$\square$ Climate \\
$\square$ Economic \\
$\square$ Family \\
$\square$ Company Policies \\
$\square$ Leadership \\
$\square$ Workload \\
$\square$ Working Conditions \\
$\square$ Timings \\
\hline
\end{tabular}

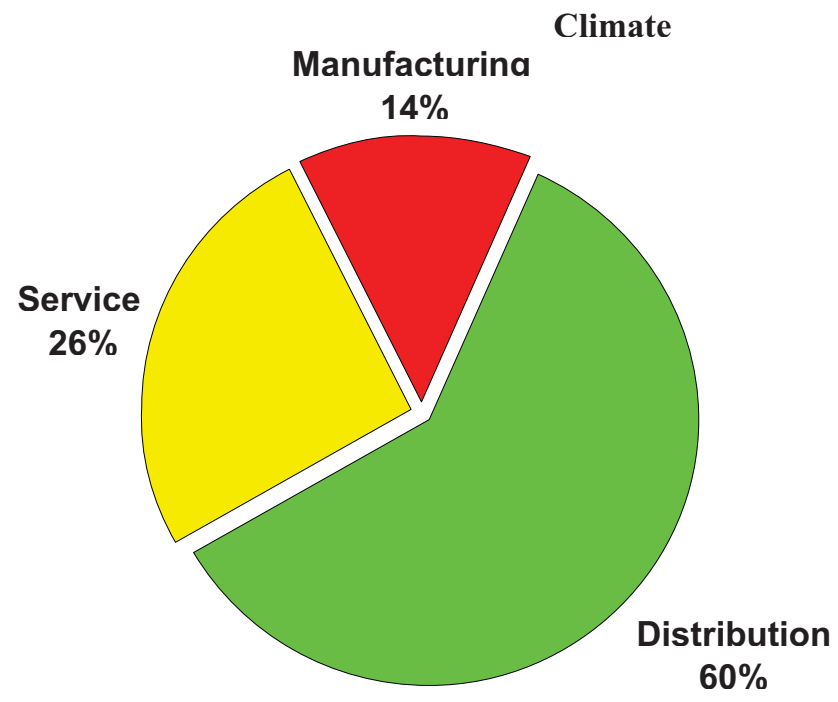

$\square$ Service

Manufacturina

$\square$ Distribution

Figure 7. 


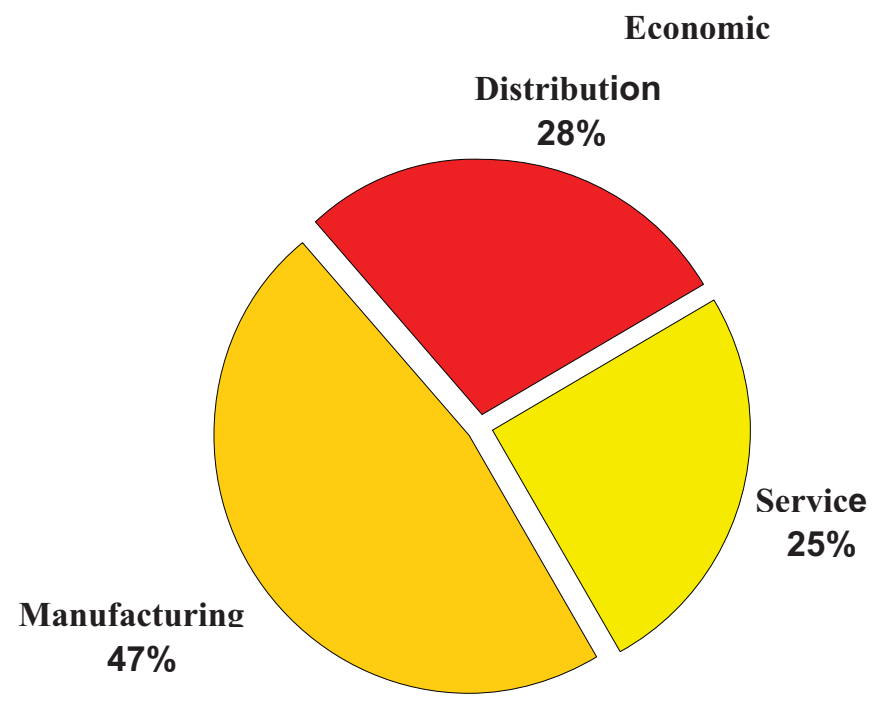

Figure 8.
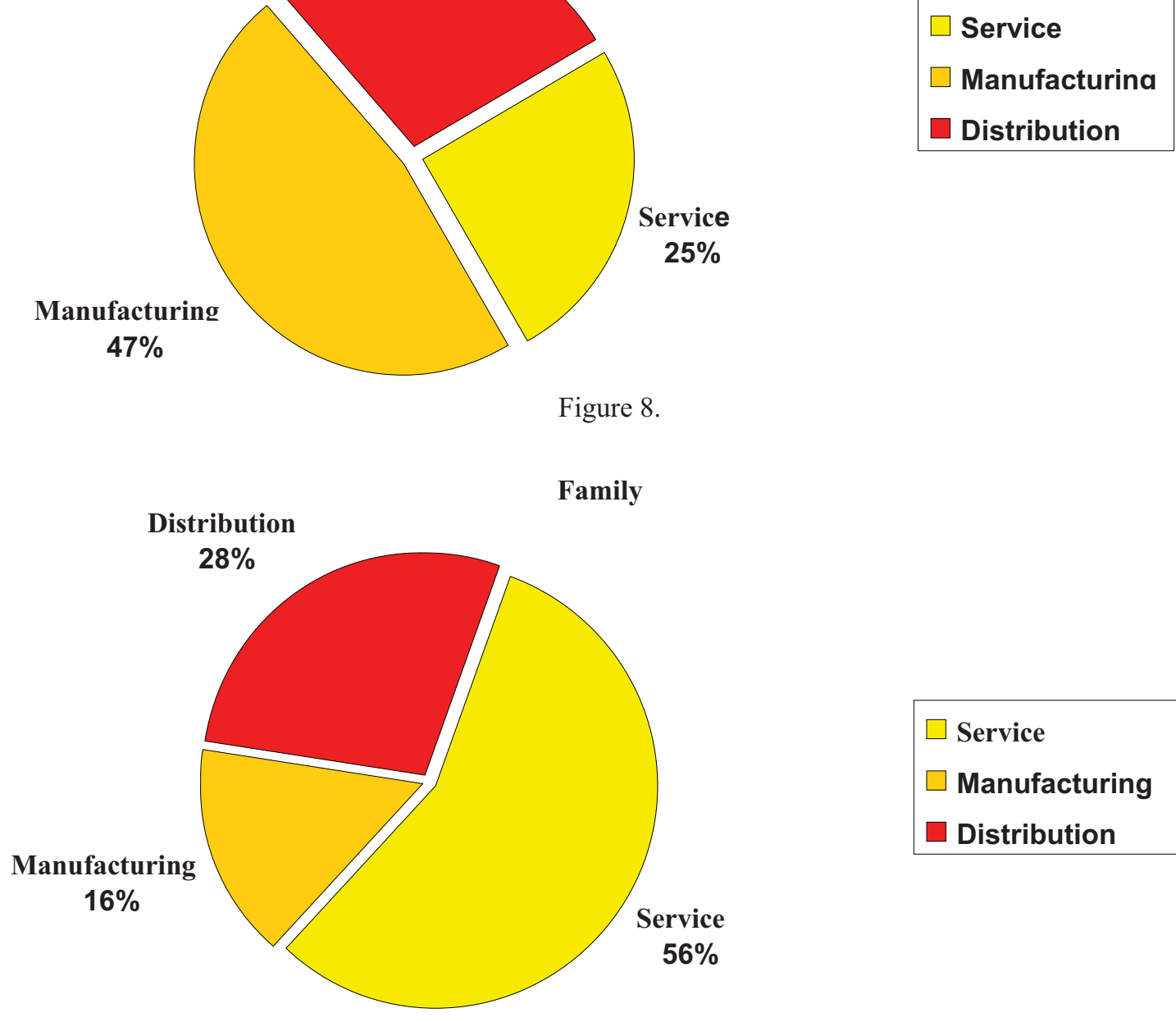

ervice

$25 \%$

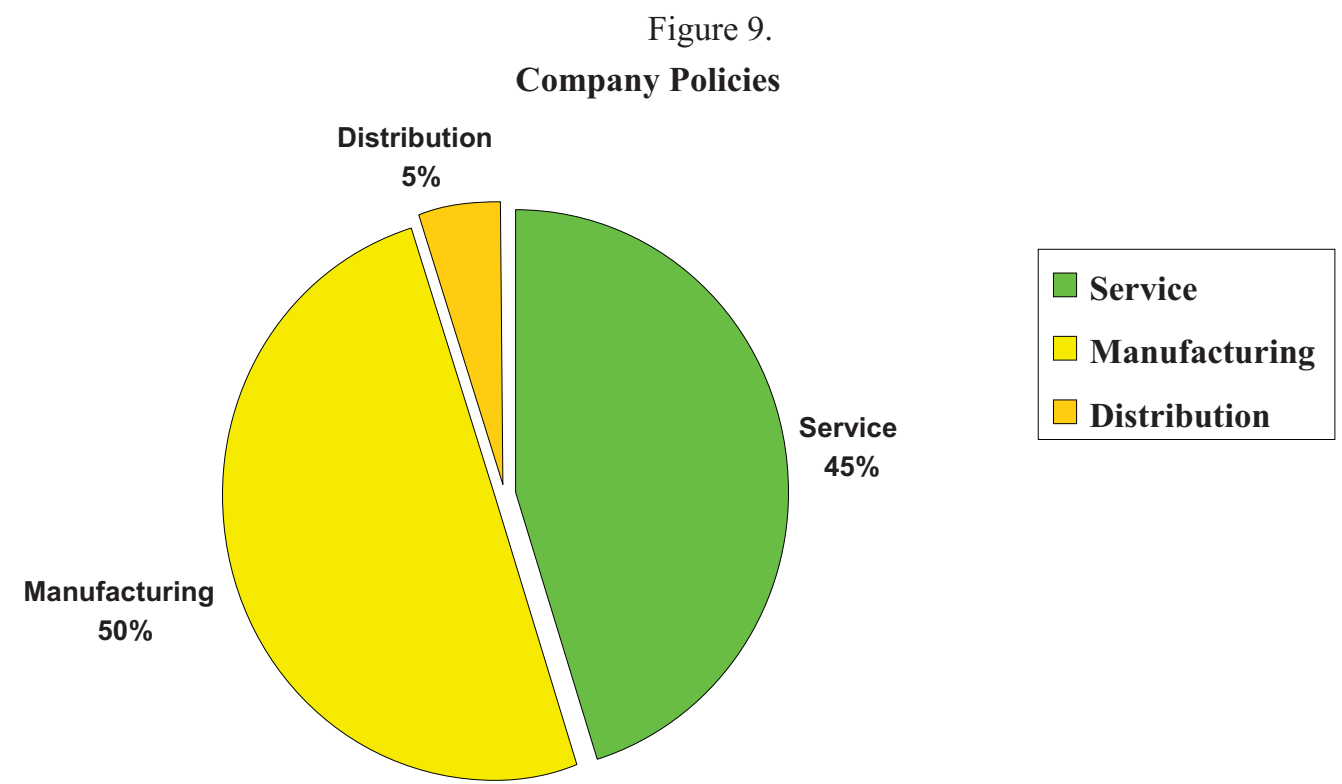

Figure 10. 

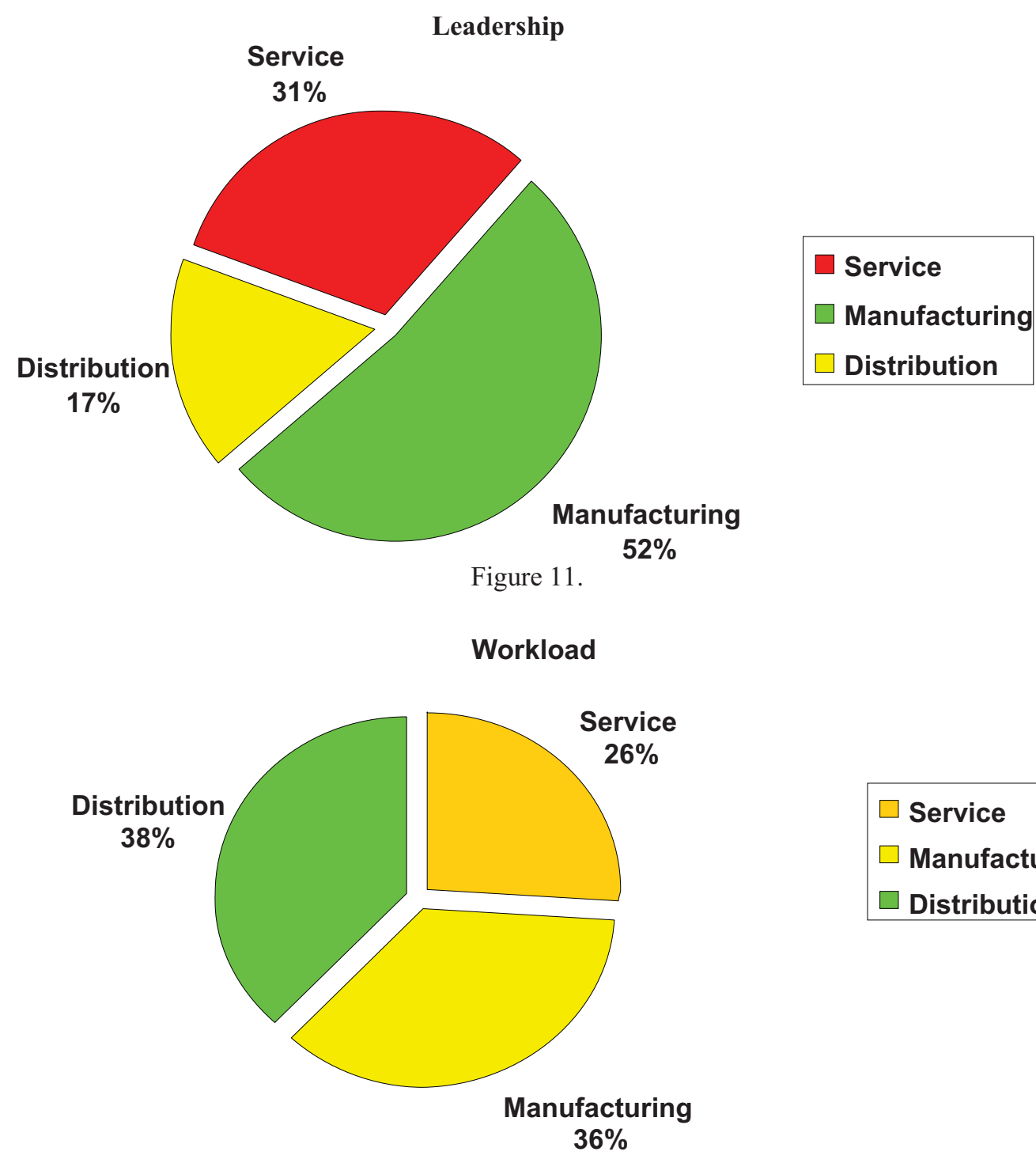

Figure 12.
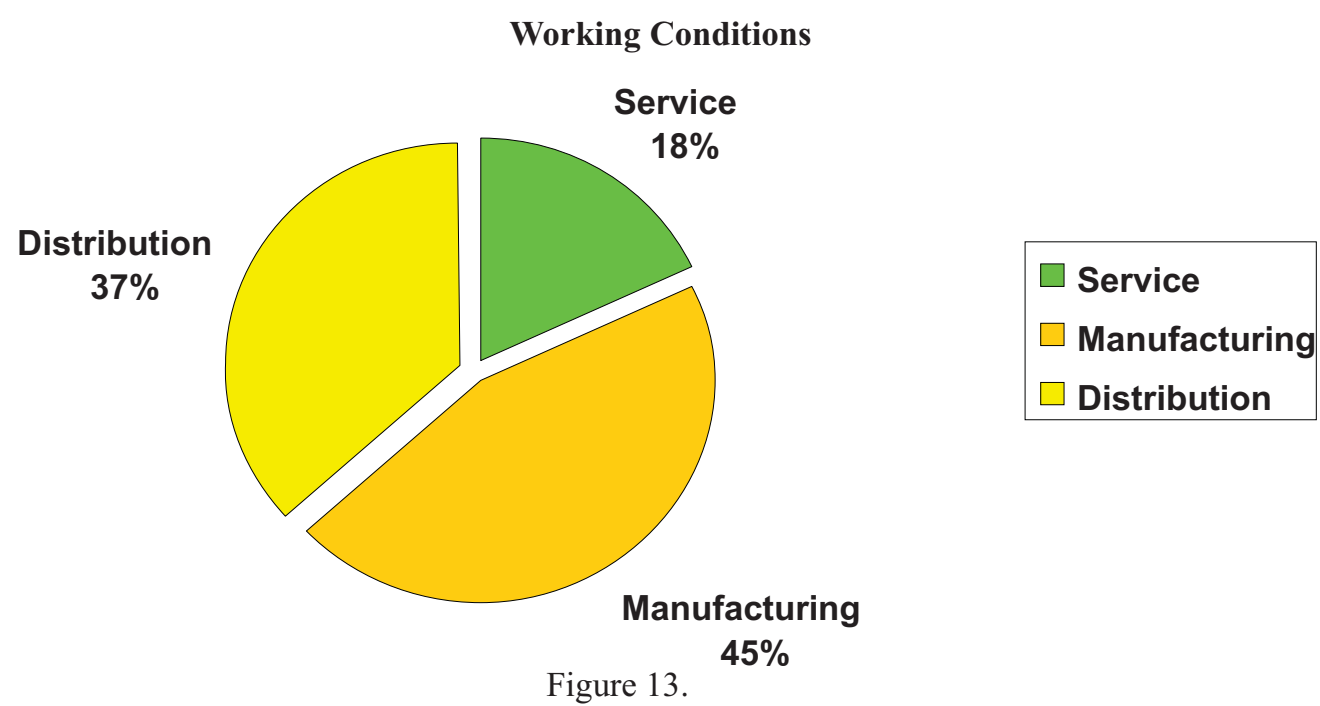